\title{
Best Practices of Capital City Relocation in Various Countries: Literature Review
}

\author{
Rini Rachmawati ${ }^{1 *}$, Eko Haryono ${ }^{2}$, Rizki Adriadi Ghiffari ${ }^{1}$, Hilary Reinhart ${ }^{1}$, Farah Dewi Permatasari ${ }^{3}$, and Amandita \\ Ainur Rohmah ${ }^{4}$ \\ ${ }^{1}$ Department of Development Geography, Faculty of Geography, Universitas Gadjah Mada, Yogyakarta, Indonesia \\ ${ }^{2}$ Department of Environmental Geography, Faculty of Geography, Universitas Gadjah Mada, Yogyakarta, Indonesia \\ ${ }^{3}$ Graduate School on Environmental Science, Universitas Gadjah Mada, Yogyakarta, Indonesia \\ ${ }^{4}$ Graduate Program of Regional Development, Faculty of Geography, Universitas Gadjah Mada, Yogyakarta, Indonesia
}

\begin{abstract}
Capital city relocation issue is currently emerging due to the condition and problem Indonesia encounters. Study toward some cases of capital city relocation could be crucial input for analysis and comparison. This paper aims to review capital city relocation examples. Literature review shows there are variances in background and driving factors internally or externally, and infrastructure needs for city development. The driving factors consist of environmental pressure, pollution, urban heat island, housing, urban sprawl, and disaster. The infrastructures required for the development of a new capital city are information and communication technology (ICT), physical infrastructure, transportation, and open green space. From the analysis, Myanmar's Yangon to Naypyidaw relocation and Malaysia's Kuala Lumpur to Putrajaya relocation are the best practices in capital city development that boosts new activities and urban extension. Burma shows the infrastructure's role in development of a new capital city and Kuala Lumpur reveals how ICT implementation helps to establish a new capital city. This paper is expected to fill the research gap from previous research in terms of reviews related to the need for ICT in capital city preparation. This indicates that this paper has followed the trend of ICT advancement. The next research and publication will strengthen the use of ICT as one of the variables.
\end{abstract}

\section{Introduction}

The capital city relocation issue is currently becoming crucial due to several urges namely people density, environmental degradation, and urban discomfort as living space. These problems are highly important to be identified through literature review.

Capital city relocation study has already been conducted from various perspectives such as Geographical Science, Development Geography, Environmental Geography, and Urban Planning. Capital city relocation driving factors are needed to be studied from the literature review. Analysis on infrastructure development also must be considered in supporting new capital city development. Examples of required infrastructures are public facilities which consist of hospitals, art, and sports facilities, library, market, urban transportation, and housing.

The new capital city requires a novel urban development strategy as described by the National Urban Development Project (NUDP). NUDP elaborates urban development that integrates infrastructure through three schemes: encouraging harmonious policy and institution in city development agenda, increasing integrated planning for city investment based on spatial planning framework, and formulating criteria and mechanism that prioritize investment, identification of funding gap and enhancing local government's financial management capacity.

Information and Communication Technology (ICT) on urbanization is not merely a people or residents' movement but also a social adaptation in associating traditional behavior with urban life characters [1]. It also relates to technological changes which are caused by the human behavior model in the city [2]. The city undergoes rapid development in many aspects including ICT. People in the city are quickly engaged with the lifestyle changes, particularly with high technologybased and at the end, the information technology brings lifestyle changes [3]. Hence, ICT usage triggers urbanization and it recently has encompassed all the globe especially in urban areas. Researchers try to match the ICT application with urban structure. Therefore, ICT applications must be included in this research.

Review toward capital city relocation literature is important to fathom initial problems and conditions from several countries. It also can be a scientific base and reference before field survey. A literature review is also expected to identify background, strength, and weakness as supporting factors and constraints, also the plan that has been implemented in the capital city relocation.

\footnotetext{
* Corresponding author: rinirachma@ugm.ac.id
} 


\section{Background of Capital City Relocation}

Capital city is very dense, and it is a place where history was written amid high political and economic functionality. For centuries, several governments have decided to move their capital city across the globe. Some capital cities were planned to be located in lessdeveloped regions to distribute the development [4].

Authorities also relocate their capital city to decrease the big city control on them. Thus, cooperation or power-sharing would be created and facilitate competition and interest-sharing which is geographically concentrated. It is expected to minimize civilian conflicts [5]. State also moves their city for reasons like geographical aspects which are related to whether the security and government center is strategic or not. Another reason is to distribute the development, security reason, and historical background [6].

After World War 2, 16 countries have relocated their capital city [7, 8]. During the 20th century, Montenegro was the first country to relocate the capital city from Cetinja to Podgorica in 1946 and Malaysia was the latest to move its capital city from Kuala Lumpur to Putrajaya in 2000 . In the 21 st century, there are two countries that move their capital city: Tanzania and Myanmar. Tanzania even moved its capital city twice -a unique case, from Dar Es Salaam to Dodoma in 1973 and back to Dar Es Salaam again in 2016. A list of countries that relocate to the capital city can be seen in Table 1 .

Table 1. List of Countries that Relocate the Capital City

\begin{tabular}{|c|c|c|c|}
\hline Year & Countries & $\begin{array}{c}\text { Previous } \\
\text { Capital } \\
\text { City }\end{array}$ & $\begin{array}{c}\text { New Capital } \\
\text { City }\end{array}$ \\
\hline 1946 & Montenegro & Cetinje & Podgorica \\
\hline 1956 & Brazil & $\begin{array}{l}\text { Rio de } \\
\text { Janeiro }\end{array}$ & Brasilia \\
\hline 1957 & Mauritania & $\begin{array}{l}\text { Saint } \\
\text { Louis }\end{array}$ & Nouakchott \\
\hline 1959 & Pakistan & Karachi & Islamabad \\
\hline 1961 & Botswana & Mafeking & Gaberone \\
\hline 1963 & Libya & Benghazi & Tripoli \\
\hline 1965 & Malawi & Zomba & Liliongwe \\
\hline 1970 & Belize & $\begin{array}{l}\text { Belize } \\
\text { City }\end{array}$ & Belmopan \\
\hline 1973 & Tanzania & $\begin{array}{l}\text { Dar es } \\
\text { Salaam }\end{array}$ & Dodoma \\
\hline 1974 & Guinea Bissau & Boe & Bissau \\
\hline 1975 & Nigeria & Lagos & Abuja \\
\hline
\end{tabular}

\begin{tabular}{llll}
1982 & Srilanka & Colombo & $\begin{array}{l}\text { Sri } \\
\text { Jayawardenapu } \\
\text { ra Kotte }\end{array}$ \\
1983 & Cote d'Ivoire & Abidjan & Yamoussoukro \\
1990 & Germany & Bonn & Berlin \\
1997 & Kazakhstan & Almaty & Astana \\
2000 & Malaysia & $\begin{array}{l}\text { Kuala } \\
\text { Lumpur }\end{array}$ & Putrajaya \\
2005 & Myanmar & Rangoon & Naypyidaw \\
2016 & Tanzania & Dodoma & Dar Es Salaam \\
\hline
\end{tabular}

Sources: $[7,8]$

In the South-East Asia Region, Myanmar and Malaysia are examples of countries that relocate their capital city. In the case of Myanmar, capital city relocation was done under geographical motive and warfare history, representing Myanmar's military response toward invasion probability [9]. Moreover, Naypyitaw as the new capital city was selected because the location was more centered than Yangon. The Naypyidaw capital city structure is composed of a city center surrounded by eight small cities. This city is managed by Naypyitaw Development Center (NPTDC) and this area is called Naypyidaw Union Territory (NUT). Naypyitaw's location is also strategic because Naypyitaw International Airport is only $16 \mathrm{~km}$ from town and is supported by Yangon-Naypyidaw Highway and those two facilities provide intercity transportation [10].

Malaysia, instead of totally relocating its capital city, only transferred some of its administrative function to Putrajaya. Administrative center relocation creates a better chance of having a more well-planned town center complemented by modern technology and adequate infrastructure to increase the government's efficiency and productivity [11]. Kuala Lumpur to Putrajaya relocation was also driven by the motivation to enforce national identity and gaining global recognition. Putrajaya is a good example of Malaysia's urban design and exhibits various contemporary urban development philosophies, especially the effort to manifest sustainable and smart cities [11]. To summarize, the background of Myanmar and Malaysia's capital city relocation can be seen in Table 2 .

Table 2. Summary of Myanmar and Malaysia Capital City Relocation

\begin{tabular}{|c|c|c|}
\hline Aspects & Myanmar & Malaysia \\
\hline Main pattern & $\begin{array}{l}\text { Physical } \\
\text { Infrastructure }\end{array}$ & ICT \\
\hline $\begin{array}{l}\text { Part of } \\
\text { Relocation }\end{array}$ & Total relocation & Partial relocation \\
\hline Reasons & $\begin{array}{l}\text { Warfare } \\
\text { (hard } \\
\text { element) } \\
\text { - Centrality }\end{array}$ & $\begin{array}{l}\text { Urban } \\
\text { expansion } \\
\text { (soft } \\
\text { element) }\end{array}$ \\
\hline
\end{tabular}




\section{- National identity \\ - International recognition \\ Source: Analysis (2021) \\ 3 Driving Factors of Capital City Relocation}

\subsection{Environmental Pressures}

Population growth in urban regions steadily increases and in 2030 , it is expected that $60.4 \%$ of the world population would live in cities, especially capital cities [12]. The capital city is basically different from the common city because it has three exclusive main elements of political power, reverence, and urban environment [13]. The capital city attracts people with its employment chances, economic factors, and entertainment $[14,15]$ and the increasing population inevitably gives heavy pressure on the environment along with the growth of demand and needs for every person. However, the environment's capability to provide the resources needed is naturally limited [16] and depends on the biophysical characteristics of the area. This concept of limitation is well-known as urban carrying capacity $[17,18]$.

Maintaining population growth to be still below the carrying capacity is imperative to ensure the environment can still bestow people's livelihood. If this limit is surpassed, there will be environmental deterioration entailed by disaster and eventually cut the population number through mortality or migration [19]. Environmental deterioration is indicated by pollution, land-use change, and health problems [20]. All these factors can be categorized as internal factors because it comes from the inside of a city. On the contrary, external factors arise from outside of city boundaries such as climate change and sea-level rise as can be seen in Figure 1.

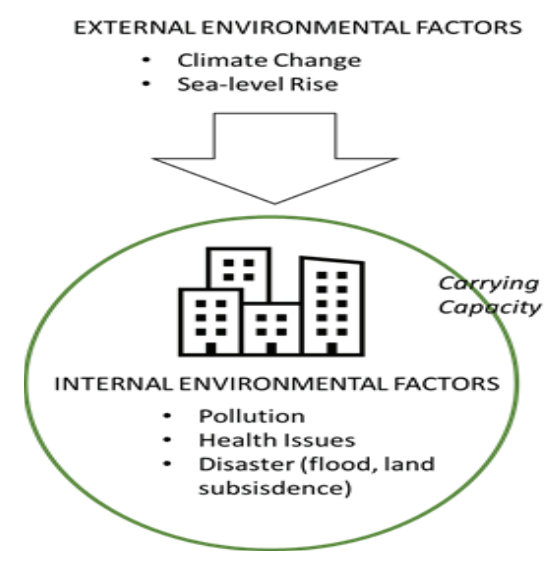

Fig. 1. External and internal environmental pressures (source: analysis, 2021)

Cases of Kuala Lumpur and Yangon relocation cannot be unattached from environmental factors such as urban carrying capacity although its main considerations are most economical and geopolitical. Urbanization in each capital city is highly rapid, it initiates environmental problems like pollution, urban heat island, housing, and urban sprawl, and natural disaster $[21,22]$. Those problems would lead to more severe impacts including air, water, and land resources depletion.

\subsection{Air Pollution}

Air pollution in Kuala Lumpur and Yangon is heavily influenced by urban expansion [23, 24] which directly increases pollutant emission from transportation [2527]. For the anticipation, a better integrated and sustainable transportation system must be employed with cleaner fuel and a cutback of vehicle numbers. Furthermore, green space also could help lessen the pollutants. These strategies could be merged into green city design. Capital city expansion such as Kuala Lumpur-Putrajaya is likely to help prevent pollution in a region and combined with green space, eliminate the pollutant from the air. Capital city expansion also relieves congestion as one of the main sources of emission.

\subsection{Urban Heat Island}

UHI is formed when a significant temperature difference between a high-density built environment and a high-vegetation area occurs. The temperature difference can reach up to $4^{\circ} \mathrm{C}$ higher and in some area at Great Kuala Lumpur like Kampung Baru, it could reach $5^{\circ} \mathrm{C}[28,29]$. Building's height difference and their dispersion trap hot air and prompt the accumulation. UHI leads to thermal discomfort, affecting public health, economical disadvantages, and pollution [30] and in Kuala Lumpur, it has been a big concern. In Yangon, Land Surface Temperature (LST) happens to keep rising as the impact of infrastructure and vegetation loss. Capital city relocation should be designed to avoid the UHI spot by regulating building heights since it is extremely difficult to adjust existing building height.

\subsection{Housing and Urban Sprawl}

Rapid urbanization in Kuala Lumpur and Yangon demands vast land for living and activity space. It directs to the decreasing land availability and on the other side tightens the competition for the remaining land, ascending its price $[31,32]$. Land scarcity also forces Kuala Lumpur and Yangon residents to seek for the land outward, causing urban sprawl. Urban sprawl degrades environmental and resources quality as the impact of higher transportation usages and vegetation loss [33].

At Yangon, urban growth follows a multicentral pattern and expanding without a firm policy causing land competition [32, 34, 35]. As the impact, gentrification and marginalization happen which causes slums and declining residents' quality of life [36]. Capital city relocation could add land supply and spare urbanization pressure toward the environment. 


\subsection{Disaster}

Throughout history, natural disasters like volcanic eruptions and floods are the main driving factors in capital city relocation [13]. Ancient capital cities are usually built adjacent to the shore or river delta [37] due to the accessibility but it is prone to a natural disaster.

Both Kuala Lumpur and Yangon are located near the coast where Yangon lies in the Irrawaddy River Delta. This location puts Yangon in an open exposure to flood, cyclone, and sea-level rise and the risk is getting higher along with the urban expansion [38, 39]. Yangon is also threatened by land subsidence [40] caused by heavy burden and groundwater exploitation. Kuala Lumpur, although its location is relatively far 'deeper' than Yangon, is frequently hit by flash floods caused by poor drainage, land-use change, and naturally because Kuala Lumpur sits in the Klang Flood Plain [41, 42]. Relocation of the capital city could minimize the exposure by selecting a safer location and the new capital city could be designed to be more adaptive to the disaster.

\subsection{Geographic Centrality}

Centrality is related to the equal distance affordability amongst regions in a country [43]. Based on that consideration, the capital city is ideally located at the centroid point of a country hence it can reach the whole country and people more efficiently [44]. The example of centrality can be seen in Malawi, Brazil, and Burma cases where the centrality of Naypyidaw connects the highland of Mandalay with the lowland part of Yangon [45]. The summary of environmental factors can be seen in Table 3.

Table 3. Environmental Factor that Affects Capital City Relocation

\begin{tabular}{ccll}
\hline Factor & Intensity & Resource & \multicolumn{1}{c}{ Explanation } \\
\hline Pollution & Low & $\begin{array}{l}\text { Air } \\
\text { Resources, } \\
\text { Water } \\
\text { Resources }\end{array}$ & $\begin{array}{l}\text { Air and water } \\
\text { pollution } \\
\text { decrease public } \\
\text { health }\end{array}$ \\
& & Air \\
UHI & Low & $\begin{array}{l}\text { Has negative } \\
\text { impact towards } \\
\text { thermal comfort }\end{array}$ \\
& & $\begin{array}{l}\text { Increases } \\
\text { emission along } \\
\text { with the usage } \\
\text { of air } \\
\text { conditioner and } \\
\text { cooling system }\end{array}$ \\
& & &
\end{tabular}

\begin{tabular}{|c|c|c|c|}
\hline \multirow[t]{3}{*}{ Housing } & \multirow[t]{3}{*}{ Low } & \multirow[t]{3}{*}{$\begin{array}{l}\text { Land } \\
\text { resources }\end{array}$} & $\begin{array}{l}\text { Higher land } \\
\text { price }\end{array}$ \\
\hline & & & Marginalization \\
\hline & & & Slums \\
\hline \multirow[t]{2}{*}{$\begin{array}{l}\text { Urban } \\
\text { Sprawl }\end{array}$} & \multirow[t]{2}{*}{$\begin{array}{l}\text { Medium- } \\
\text { high }\end{array}$} & \multirow{2}{*}{$\begin{array}{l}\text { Land } \\
\text { resources, } \\
\text { air resources }\end{array}$} & Vegetation loss \\
\hline & & & $\begin{array}{l}\text { Increasing } \\
\text { emission from } \\
\text { transportation }\end{array}$ \\
\hline \multirow[t]{3}{*}{ Disaster } & \multirow[t]{3}{*}{ High } & \multirow{3}{*}{$\begin{array}{l}\text { Water } \\
\text { resource, air } \\
\text { resource, } \\
\text { land } \\
\text { resource }\end{array}$} & $\begin{array}{l}\text { Infrastructure } \\
\text { damage }\end{array}$ \\
\hline & & & Economical loss \\
\hline & & & Casualties \\
\hline
\end{tabular}

Source: Analysis (2021)

\section{Infrastructure for capital city development}

A complete and modern infrastructure construction has a noteworthy impact on government functionality. Technological development in this digital era in the term of digital governance becomes a notable factor to organize a state. Nowadays, the government is obliged to have easy and quick information access to strengthen central government control. Dynamic urban development yields innovation opportunities in managing governmentality. Therefore, innovation is fundamentally beneficial for the public and institution.

Governmentality must adapt to the latest technology by adopting the concept of Internet of Things (IoT), cloud computing, to Artificial Intelligence. Latest technology alleviates administration loads thus the function of planning, organizing, and monitoringevaluation will run more effectively. ICT-based also could support public services accessibility and smart city implementation [46].

Capital city is supposed to be livable and smart for its people [47]. Government institutions in the new capital city must employ ICT that could provide competitiveness for the governments where they must perform effective, efficient, and transparent services for the people [46, 48, 49]. ICT could also contribute to education, health, commerce, and the government sector. Smart cities also elevate people's quality of life by accelerating economic development $[47,50]$.

From the regional development and environment point of view, infrastructure of the capital city should be planned under demand and good space capability consideration. One of the government visions in relocating the capital city according to Chin [51] and Moser [11] is to build a city that will be able to reflect the natural and cultural heritage of the country. It is also important to optimize technological capacity combined with state-of-the-art facilities to anticipate future challenges. Currently ICT has been implemented in all aspects of urban development and plays an important 
role in the future of cities. Among them are related to the provision of government services and social services, such as health, economy, and education in the form of ICT-based applications that support smart city implementation [52].

In the Kuala Lumpur case, the relocation of an administration that is close to Cyberjaya results in a chance to amalgamate the latest technology with smart city [51].

Infrastructure must address sustainability and people's interests. Putrajaya is designated as Garden City that harmonizes city development and management with surrounding nature. Putrajaya development considers urban life quality with open-space recreation hence the people could experience various entertainments, sports, and recreational activities. Many buildings in Putrajaya are designed to be attractive as icons and create comfort for the people. Capital city relocation that puts identity and character which roots on locality and tradition forward and center is essentially compatible with Smart City. Putrajaya is highly regarded as a remarkable work as a new administrative center.

Another aspect that determines the accomplishment of development of a new capital city is the accessibility. Putrajaya as Malaysia's new capital city is located within 20 kilometers from Kuala Lumpur International Airport (KLIA) and 25 kilometers from Kuala Lumpur. The distance helps the employees to reach their office. Putrajaya is also supported by integrated transportation modes including bus, train, and monorails. The infrastructure requirements can be seen at Figure 2 .

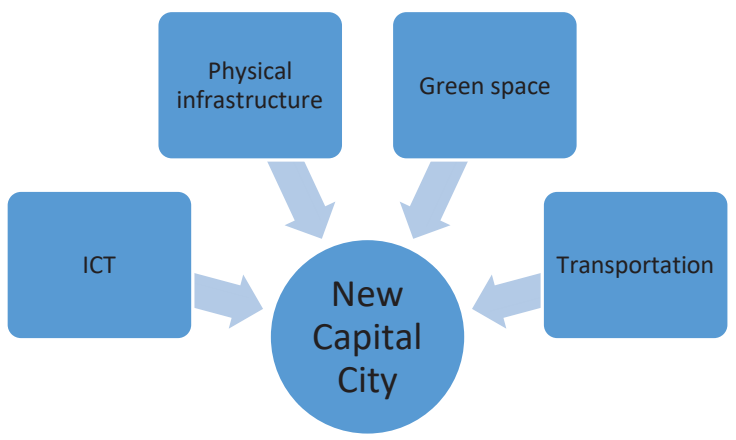

Fig. 2. Infrastructure for New Capital City (source: analysis, 2021)

\section{Conclusion}

Literature review shows there are various capital city relocation backgrounds, encouraging and discouraging factors internally or externally namely environmental pressure, pollution, UHI, housing and urban sprawl, natural disaster, and location. The infrastructure required for the urban development to be the capital city comprises ICT, social and regional development, and physical and environmental aspects. Capital city relocation of Myanmar from Yangon to Naypyidaw could be referred to as best practices during capital city development that becomes a new activity in regional development. Kuala Lumpur to Putrajaya relocation is the best practice in implementing ICT.

\section{Acknowledgments}

The authors would like to thank Universitas Gadjah Mada for supporting the research through Scheme of Penelitian Dasar (PD) in 2021, NUMBER 2169/UN1/DITLIT/DIT-LIT/PT/2021. Research Funds from the Budget Implementation Entry List (DIPA), Deputy for Strengthening Research and Development, Ministry of Research and Technology/National Research and Innovation Agency (Deputi Bidang Penguatan Riset dan Pengembangan, Kementerian Riset dan Teknologi/Badan Riset dan Inovasi Nasional) for the 2021 Budget Year.

\section{References}

1. R. Paddison, Handbook of Urban Studies, London: Sage Publications, (2001)

2. P.L. Knox and L.M. Carthy, Urbanization: An Introduction to Urban Geography, 2nd ed, (2005)P.L.

3. Knox and S.A. Marston, Place and Regions in Global Context Human Geography, 3rd ed, New Jersey: Pearson Education Inc, (2004)

4. Richard, Katherine Schulz. Capital City Relocation. accessed from https://www.thoughtco.com/capitalcity-relocation-1435389 on August 18th 2019.

5. A. Potter, Locating the government: Capital cities and civil conflict, Research and Politics, 4, 4 (2017)

6. Ilman, 2015

7. M. Mubaroq and A. Solikin, Review on the Financing Scheme of Indonesia's Capital City Relocation Plan: Lessons Learned from Brazil, Malaysia, and Tanzania," in ICOFEB 2018, Lhokseumawe: EAI, (2019)

8. D. K. Ishenda, and S. Guoqing, Determinants in Relocation of Capital Cities J. of Public Administration and Governance 9 4, 200 (2019)

9. D. Preecharushh, Naypyidaw: New Captial of Burma, Bangkok: White Lotus (2009)

10. A. M. bin A. Manan and H. Suprayitno, Preliminary Overview of Several Capital Relocations in Relationship with a Plan of Indonesian Capital Relocation J. Infrastruct. Facil. Asset Manag, 2, 1 (2020)

11. S. Moser, Putrajaya: Malaysia's new federal administrative capital. Cities 27, 4 (2010)

12. United Nation, World Population Report 2018, (2019)

13. V. Rossman, Capital Cities: Varieties and Patterns of Development and Relocation, Routledge: Amsterdam, (2017)

14. Ischak, Urbanisasi Dan Dampaknya Terhadap Lingkungan. Humaniora 13, 2 (2001)

15. I. Suntajaya, Piramida, Faktor-Fator Yang Mempengaruhi Terjadinya Urbanisasi Di Provinsi Bali. 10, 2 (2014) 
16. H. Wahyuningsih, Perhitungan Ruang Terbuka Hijau Perkotaan Jenis Publik (Studi Kasus: Kota Surakarta). J. Arsit. dan Perenc, 1, 2 (2018)

17. Y. Su, H. Xue, H. Liang, An Evaluation Model for Urban Comprehensive Carrying Capacity: An Empirical Case from Harbin City. Int. J. Environ. Res. Public Health 16, 367 (2019)

18. Y. Wei, C. Huang, J. Li, L. Xie, An evaluation model for urban carrying capacity: A case study of China's mega-cities. Habitat Int., 53 (2016)

19. A. R. Khavarian-Garmsir, A. Pourahmad, H. Hataminejad, and R. Farhoodi, Climate change and environmental degradation and the drivers of migration in the context of shrinking cities: A case study of Khuzestan province, Iran. Cities Soc., 47 (2019)

20. C. S. S. Ferreira, R. P. D. Walsh and A. J. D. Ferreira, Degradation in urban areas. Environmental Science \& Health 5, pp. 19-25, (2018)

21. H. C. Siong, Urban governance and rapid urbanization issues in Malaysia. Jurnal Alam Bina 13, 4 (2008)

22. C. Wang, S. W. Myint, P. Fan, M. Stuhlmacher, J. Yang, The impact of urban expansion on the regional environment in Myanmar: a case study of two capital cities. Landscape Ecol., 33 (2018)

23. O. H. L. Ling, K. H. Ting, A. Shaharuddin, A. Kadaruddin and M. J. Yaakob, Urban growth and air quality in Kuala Lumpur city, Malaysia. EnvironmentAsia 3, 2 (2010)

24. M. A. B. A. Tajudin, M. F. Khan, W. R. W. Mahiyuddin, R. Hod, M. T. Latif, A. H. Hamid, S. A. Rahman, M. Sahani, Risk of concentrations of major air pollutants on the prevalence of cardiovascular and respiratory diseases in urbanized area of Kuala Lumpur, Malaysia. J. Ecotoxicology and Environmental Safety, 171 (2019)

25. M. F. Khan, A.H. Hamid, M. A. Bari, A. B. A. Tajudin, M. T. Latif, M. S. M. Nadzir, M. Sahani, M. I. A. Wahab, Y. Yusup, K. N. A. Maulud, M. F. Yusoff, N. Amin, MdAkhtaruzzaman, W. Kindzierski, P. Kumar, Airborne particles in the city center of Kuala Lumpur: Origin, potential driving factors, and deposition flux in human respiratory airways. J. Sci. of the Total Env., 650 (2019)

26. L. N. Huy, N. T. K. Oanh, T. T. Htut, O. M. T. Hlaing, Emission Inventory for On-road Traffic Fleets in Greater Yangon, Myanmar. Atmospheric Pollution Research, 11 (2020)

27. W. Y. Aung, M. Noguchi, E. P. Yi, Z. Thant, S. Uchiyama, T. Win-Shwe, N. Kunugita, O. Mar, Preliminary assessment of outdoor and indoor air quality in Yangon city, Myanmar. Atmospheric Pollution Research, 10 (2019)

28. Lin Yola, 2018. Impact of Urban Configurations on Microclimate and Thermal Comfort in Residential Area of Kuala Lumpur. Dissertation. Faculty of Built Environment Universiti Teknologi Malaysia

29. S. A. Zaki, N. S. Azid, M. F. Shahidan, M. Z. Hassan, M. Y. M. Daud, N. A. A. Bakar, M. S. A. Ali, F. Yakub, Analysis of Urban Morphological Effect on the Microclimate of the Urban Residential
Area of Kampung Baru in Kuala Lumpur Using a Geospatial Approach. Sustainability, 12 (2020)

30. I. S. M. Elsayed, Mitigation of the urban heat island of the city of Kuala Lumpur, Malaysia. Middle-East J. of Scientific Research 11, 11 (2012)

31. N. Wahi, R. M. Zin, V. Munikanan, I. Mohamad, S. Junaini, Problems and Issues of High Rise Low Cost Housing in Malaysia. IOP Conf. Series: Materials Science and Engineering 341 (2018)

32. M. Sabrié, Yangon "Emerging Metropolis": Challenges for the Authorities and Resilience of the Yangonites. Moussons: Recherche en sciences humaines sur l'Asie du Sud-Est, 33 (2019)

33. M. A. Naeema, Malaysia Sustainable Cities Program, Working Paper Series (2016)

34. T. Sritarapipat, W. Takeuchi, Modeling urban expansion in Yangon, Myanmar using Landsat timeseries and stereo GeoEye Images. IOP Conf. Series: Earth and Environmental Science 37 (2016)

35. S. S. Moe, Current Trends of Urban Development in Yangon City and Its Implications on the Environment. GMSARN Int. J., 3 (2009)

36. M. Matelski, M. Sabrié, Challenges and Resilience in Myanmar's Urbanization: A Special Issue on Yangon. Moussons: Recherche en sciences humaines sur l'Asie du Sud-Est, 33 (2019)

37. B. Karsono, Historical analysis of urbanity on the waterfront. ARSITEKNO, 2 (2013)

38. G. Fernandez, A. M. Tun, K. Okazaki, S. H. Zaw, K. Kyaw. Factors influencing fire, earthquake, and cyclone risk perception in Yangon, Myanmar. Int. J. of Disaster Risk Reduction, 28 (2018)

39. L. Tierolf, H. de Moel, J. van Vliet, Modeling urban development and its exposure to river flood risk in Southeast Asia. Computers, Environment and Urban Systems, 87 (2021)

40. T. v. d. Horst, M. M. Rutten, N. C. v. d. Giesen, R. F. Hanssen, Monitoring land subsidence in Yangon, Myanmar using Sentinel-1 persistent scatterer interferometry and assessment of driving mechanisms. Remote Sensing of Environment, 217 (2018)

41. N. Samsuri, R. A. Bakar, T. Unjah, Flash Flood Impact in Kuala Lumpur - Approach Review and Way Forward, Int. J. of the Malay World and Civilisation (Special Issue 1), 6 (2018)

42. T.R. Bhuiyan, M. I. H. Reza, E. A. Choy, J. J., Pereira, Facts and trends of urban exposure to flash flood: A case of kuala lumpur city, Community, Environment and Disaster Risk Management, 20 (2018)

43. F. Homburg, Capital Cities, Journal of Geography 19, 1, pp. 8-15 (1920)

44. D. Potts, Capital Relocation in Africa: The Case of Lilongwe in Malawi, The Geographical J. 151, 2 (1985)

45. D. M. Seekins, 'Runaway chickens' and Myanmar identity, City 13, 1 (2009)

46. R. Rachmawati, P. Rachmadani, V. N. Anifa, and F. Lutfiana, Various ICT-based applications and their uses to support smart city implementation in the Regency of Blora, in E3S Web Conf, 200, (2020) 
47. Kementerian Luar Negeri, Pustaka Aditya: Perpindahan Ibu Kota Negara di Mata Diaspora Jepang, (2020)

48. E D Canedo, A P M do Vale, R L Patrão, L C de Souza, R M Gravina, V E dos Reis, F L L Mendonça and $\mathrm{R} \mathrm{T}$ de Sousa, Jr., Information and Communication Technology (ICT) Governance Proceses: A Case Study, Information 11, 1, (2020)

49. R. Rachmawati, E. R. Ramadhan, and A. 'Ainur Rohmah, Aplikasi Smart Province 'Jogja Istimewa': Penyediaan Informasi Terintegrasi dan Pemanfaatannya, Maj. Geogr. Indones 32, 1 (2018)

50. R. Rachmawati, ICT-Based Innovation in the Smart City Masterplan and Its Relation to Regional Planning, in IOP Conf. Ser. Earth Environ. Sci, 328, 1, (2019)

51. H. S. Chin, Putrajaya Administrative Centre of Malaysia Planning Concept and Implementation, Sus. urban devt Gov. Conf. Seoul, pp. 1-20, (2006)

52. R. Rachmawati, A.D. Sari, H.A.R. Sukawan, I.M.A. Widhyastana, and R.A. Ghiffari. The Use of ICT-Based Applications to Support the Implementation of Smart Cities during the COVID19 Pandemic in Indonesia. Infrastructure 6, 119 (2021) 